\title{
(DE)SACRALIZAREA TERORISMULUI: ASPECTE ALE ONOMASTICII MALADIVULUI ÎN CLIŞEELE MEDIATICE
}

\author{
Armanda Ramona Stroia \\ Universitatea Tehnică din Cluj-Napoca \\ Centrul Universitar Nord Baia Mare, România
}

\section{(De)sacralization of terrorism: aspects of names of diseases in journalistic clichés}

\begin{abstract}
The present study aims to analyse linguistic clichés based on the generic names of illnesses and disease symptoms associated with terrorism in online media discourse, both with tools from political semantics, pragmastylistics, lexicology, and with those offered by media studies (agenda setting, hegemonic vision, constructivist perspective etc.).

Apparently, the current jihadist terrorism and sacredness are incompatible notions without a common denominator. However, between the two complex phenomena one can identify a connection by referring to the origins of terrorism. In this sense, the semantic overtones of the term jihad have generated, in time, an ideological clash between Western and Islamic cultures, on the one hand, and even among adherents of the religion in question, on the other. If initially jihad meant an 'inner struggle' with one's weaknesses in order to achieve spiritual perfection, the word later came to designate the 'holy war' or struggle for global Islamization, converted into a 'divine law' for the followers of the Islamic prophet Muhammad.

In this context, we will investigate the relationship of terrorism with desacralisation, visible in the previously mentioned semantic mutation and also reflected in the current media landscape, particularly in the lexical-semantic field of names of diseases.
\end{abstract}

Keywords: terrorism, sacred, profane, disease, linguistic cliché.

\section{Preliminarii}

\subsection{Obiectivele cercetării}

Prezentul studiu pornește de la investigarea relației controversate dintre sacru și violență în contextul terorismului alimentat de jihadism (ca eveniment mediatic ce a captat atenția la nivel global) pentru a releva aspecte ale onomasticii maladivului surprinse în automatismele lingvistice care circulă în discursul media.

Obiectivul cercetării îl constituie analiza pragmastilistică și contextuală a numelor generice de boli și a manifestărilor maladive (tumoare, metastază, cancer, flagel, virus, sindrom, epidemie, febră, plagă) cu care este asociat terorismul în clișeele mediatice. Dincolo de a fi o simplă investigație onomastică, lucrarea poate constitui un punct de 
pornire în direcția unei reflecții fertile în problematizarea unor aspecte sensibile, ce țin de conceptualizare, manipulare ideologică.

Obiectivele propuse în studiul de față se subsumează unui set de întrebări esențiale care ne-au jalonat investigația:

a. Care este conexiunea dintre violență și sacru în contextul terorismului jihadist?

b. Care sunt consecințele reprezentării mediatice a terorismului ca o boală letală, incurabilă pe plan ideologic, diplomatic sau în cadrul relațiilor internaționale?

c. Există o predilecție pentru asocierea terorismului cu anumite tipuri de boli (cronice, mentale, emoționale)?

Din punct de vedere metodologic, în vederea asigurării unui demers analitic pertinent, am optat pentru metode conjugate de investigare (semantică politică, lexicologie, pragmastilistică, onomastică, analiza de conținut cu instrumente, concepte operaționale și modele teoretice explicative din aria studiilor media - teoriile de tip agenda setting, viziunea hegemonică, perspectiva constructivistă).

\subsection{Terorismul și discursul mediatic: o relație simbiotică într-un „spațiu al bricolajului simbolic" (Coman 2003: 103)}

În logica societății globalizate, obsedată de mirajul conectivității permanente, a unei societăți privilegiate în ceea ce privește accesul rapid la informație, terorismul este un subiect care „se vinde”. Această vulnerabilitate sau dependență de informație a lumii contemporane, dominate, în viziunea lui Baudrillard, de violența de consum, plasează, așadar, jurnalistul într-o poziție delicată. De aici derivă și dificultatea reprezentărilor mediatice și relația controversată dintre mass-media și terorism: cum poate discursul mediatic să evite propagarea terorii dar, în același timp, să prezinte fenomenul detașat, rațional, fără a cădea în capcana unui discurs discriminatoriu la adresa întregii comunități islamice?

Prin urmare, abordarea actelor de terorism ${ }^{1}$ constituie un exercițiu mediatic extrem de dificil, deoarece reprezentarea în termeni obiectivi - în sensul producerii unui discurs rațional despre violență - dă naștere unei situații care frizează paradoxalul: „jurnaliștii trebuie să vorbească despre fapte, despre autorii lor și, adesea, despre motivațiile lor, însă trebuie, de asemenea, să evite publicitatea pe care acești autori o vânează prin intermediul discursului mass-mediei. (...) pe de altă parte, în goana după senzațional, media este interesată să prezinte cu lux de amănunte acțiunile teroriste, contribuind, involuntar, la atingerea obiectivelor grupării teroriste" (Garcin-Marrou 2005: 6).

O analiză succintă a funcțiilor mass-mediei și a mecanismelor de operare cu

1 Studiile consacrate în epistemologia terorii (Wilkinson 1997, Hudson et al. 1999, Wieviorka 2004, Garcin-Marrou 2005, Frattasio 2006, Delcea și Bădulescu 2008, Diaz Gandasegui 2009) semnalează existența unei relații interdependente simbiotice controversate, complexe între mass-media și terorism: „terorismul și mass-media se află într-o relație pe cât de complexă, pe atât de evidentă. Terorismul are nevoie de publicitate, iar mass-media are nevoie de audiență” (Delcea și Bădulescu 2008: 124). 
informația, reprezintă un pas suplimentar în înțelegerea modului de raportare la fenomenul terorismului. Pe de o parte, se observă că mass-media facilitează fluxul informațional dincolo de bariere de ordin geografic, lingvistic, și, în același timp, joacă un rol semnificativ în formarea și cultivarea opiniei publice prin funcțiile de agenda setting și de selectare, interpretare și încadrare a evenimentelor (frame analysis).

Pe de altă parte, teoriile polarizate în jurul noțiunii de hegemonie mass-media valorifică teza marxistă a structurii duale a societăţii (scindarea în clase dominante și dominate) și pledează pentru funcţia instrumentală a mass-mediei, în sensul în care aceasta deține capacitatea de a domina și controla societatea, nu prin intermediul forței, ci prin aportul „mijloacelor persuasive de tip cultural-simbolic” (vezi Delcea și Bădulescu 2008: 120-121). Discursul media apare, așadar, ca „spațiu al bricolajului simbolic” (Coman 2003: 103) în care „jurnaliștii sunt niște „bricoleuri” care construiesc și reconstruiesc fără încetare edificiul simbolic al reprezentărilor culturale, folosindu-se de schemele narative, figurile, valorile și codurile disponibile în mediul lor cultural" (ibidem 2003: 103).

Odată ce înțelegem modul de operare a dispozitivului mediatic, putem conștientiza mult mai ușor unul dintre efectele controversate ale acestor strategii de bricolaj simbolic, care au condus, treptat, la „,implantarea” unor perspective distorsionate asupra realității, cum ar fi, de exemplu, înrădăcinarea în mentalul colectiv, în speță occidental, a metonimiei musulman - terorist.

\section{Terorismul: profilul caleidoscopic al conceptului}

\subsection{Aspecte conceptuale}

În jurul conceptului de terorism - fenomen versatil, controversat, dificil de încorsetat într-un algoritm explicativ - gravitează numeroase definiţii², viziuni, paradigme din zone științifice variate: jurnalism, securitate, diplomație, politică. Dificultatea derivă, aşadar, nu doar din imposibilitatea de a aglutina caleidoscopic un număr impresionant de definiții, ci, mai ales, din cauza absenței unui consens terminologic. Prin urmare, se ajunge la un scurtcircuit între discursul antiterorism de tip occidental, respectiv, la antipod, ideologia islamistă.

Desigur, fenomenul nu este nou, nici măcar pentru spațiul european, dacă ne gândim la grupările din anii '70-'90 precum Irish Republican Army (IRA) sau Euskadi Ta Askatasuna (ETA) (O’ Brien 2016: 199).

O incursiune în bibliografia de profil conturează elementele-cheie constitutive acestui fenomen, în jurul cărora se coagulează, de obicei, analizele teoretice: parametrul violenței, actorii-țintă (statul sau elemente nestatale), menționarea scopului (politic, economic, ideologic sau religios), dimensiunea asimetriei (prin prisma

2 O observație interesantă derivă din cercetările olandezilor Albert Jongman și Alex P. Schmid (2017) care au arhivat și investigat peste 100 de definiții academice și oficiale ale terorismului, analiza lor relevând o ierarhie a semelor distinctive (violența $83,5 \%$, politicul $65 \%$, frica accentuată, teroarea 51\%, amenințarea 47\%). 
căreia terorismul este perceput ca cel mai important risc asimetric la adresa securității mondiale).

\subsection{Aspecte etimologice}

Din punct de vedere etimologic, limba română a preluat termenul în discuție din lexemul francez terreur care, la rândul lui, derivă din substantivul latinesc terror, terroris, desemnând sentimentele din câmpul semantic al groazei („frică”, „spaimă”, „teamă”), provocate în mod premeditat prin mecanismele ameninţării și ale intimidării (DER 2001: 782). Interesant este că, în mitologia greacă Deimos (din gr. $\Delta \varepsilon \dot{\varepsilon} \mu o \varsigma$, „teroarea”)

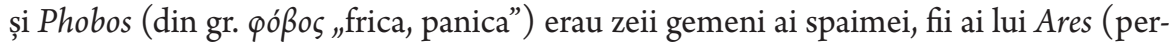
sonificarea războiului), care întruchipau manifestările daimonice ale terorii. Cei doi își însoțeau tatăl în bătălii și aveau rolul de a crea și propaga teroarea. Acest detaliu de genealogie mitologică relevă, prin urmare, la nivel simbolic, rădăcinile antice ale percepției terorii ca modalitate sistematică de folosire a fricii în vederea atingerii unui scop.

\subsection{Terorismul - act de comunicare camuflat al terorii (viziunea lui Jean-François Tétu)}

Poziția teoretică prin filtrul căreia atentatul terorist este un act de comunicare camuflat, prin urmare atipic, neconvențional, manifestat prin violență, este lansată în dezbaterea științifică de către un cercetător francez de la Institutul de Studii Politice din Lyon, Jean-François Tétu, în prefața unei lucrări de referință Media vs. Terorism semnată de Garcin-Marrou (2005). Tétu explică dificultatea definirii conceptuale a terorismului (din perspectiva teoriei comunicării) prin paradigma actului de comunicare camuflat: „vizând să obțină ceva de la adevărata sa țintă (guvernul unei anumite țări sau un organism internațional), terorismul lovește o altă țintă (individul anonim), sperând ca ecoul mediatic al atentatului să deplaseze raportul de forțe” (Garcin-Marrou 2005: 9).

\subsection{Terorismul - act de comunicare devia(n)t: teoria jocului de biliard}

În această interpretare, subordonată oarecum paradigmei comunicării camuflate, terorismul, prin modul de manifestare și comunicare, împrumută particularități ale jocului de billiard: „Pentru a ajunge la țintă (guvern, partid, instituție, organism), deci la un obiectiv oficial (reprezentativ), terorismul lovește o țintă intermediară, de regulă, un obiectiv comun (nereprezentativ) - individ, persoană anonimă, cetățean pașnic, mizând tocmai pe rolul ecoului mediatic în schimbarea raportului de forțe în favoarea sa” (David 2015: 81).

\subsection{Terorismul - act de comunicare simulat (viziunea baudrillardiană)}

Într-un eseu de referință consacrat evenimentului care a expus relația dintre violență și globalizare mediatică - atentatul din 11 septembrie 2001 - filosoful Jean Baudrillard surprinde esența fenomenului terorist într-o formulare plastică, modelată pe resorturile chiasmului: „The spectacle of terrorism forces us the terrorism of spectacle upon us” (2002: 30). Teoretician radical al societății postmoderne, acesta 
interpretează atentatul prin prisma teoriei simulacrului (vezi Baudrillard 1988: 166184), prin filtrul căreia, pe fondul mediatizării acerbe, totul glisează înspre un spațiu al hiperrealității, creat prin dizolvarea granițelor dintre realitatea evenimențială și ficțiune: „(...) reality has absorbed the energy of fiction, and became fiction itself. One could almost say that reality is jealous of fiction, that the real is jealous of the image... It is as if they duel, to find which is the most unimaginable" (Baudrillard 2002: 28).

Privit prin lentila viziunii baudrillardiene a teoriei simulacrului, terorismul, devine, așadar, o expresie a unei crize de reprezentare, un act de comunicare simulat, distorsionat, în acord cu percepția care jalonează gândirea tipică civilizației imaginii, populată de homini digitalis: a devenit real numai ce poate fi surprins în direct, ceea ce problematizează chestiunea unui mimesis în sens invers.

\section{Terorismul între spectacolul violenței şi războiul sacru}

Una dintre tendințele societății contemporane este de a multiplica spectacolul mediatic, având în vedere faptul că spectacolul în sine a devenit unul din pilonii în jurul căruia gravitează economia, politica, societatea, știrile televizate, cultura tabloidă: „Every form of culture and more and more spheres of social life are permeated by the logic of the spectacle (Kellner 2015: 3).

\subsection{Violența sacră sau despre ,alura transcendentală a violenţei" (Hodge 2016: 250)}

Sacrul, ca realitate aparent inseparabilă de experiența religioasă continuă să capteze interesul cercetătorilor în ciuda îndepărtării de religios, specifică mentalității contemporane. Întrebarea care se naște în acest context ar putea fi formulată astfel: în ce măsură putem conecta „categoria antropologică a sacrului cu vicisitudinile violenței” (Esmail 2007: 245)?

Investigațiile și contribuțiile asupra violenței provin dintr-un spectru științific variat, de la studiile biobehavioriste, neuroștiințe, până la psihanaliză, antropologie, religie. Astfel, psihanaliza indică faptul că „formele epidemice de violență” trebuie căutate în „transformarea sau degradarea identității” (Esmail 2007: 245), dar și în conceptul de identitate totală a lui Erik H. Erikson. Desigur, violența religioasă implică reprezentări ale sacrului.

Intr-un studiu asupra ambivalenței sacrului, The Ambivalence of the Sacred: Religion, Violence and Reconciliation, Scott Appleby (2000) semnalează faptul că liderii etnici și naționaliști exploatează arsenalul ideologic al religiei pentru a-și sacraliza și legitima interesele, luptele politice. De altfel, religia, în forma sa pervertită de „idolatrie ideologică” reprezintă pentru antropologul francez René Girard (1995) unul dintre „embrionii” ideologici ai violenței fundamentaliste, motiv pentru care și-a construit o întreagă pledoarie în jurul premisei controversate conform căreia „violența constituie adevărata inimă și sufletul secret al sacrului” (Girard 1995: 37).

Există studii care demonstrează că, în comparație cu cele nonreligioase, conflictele religioase sunt mult mai violente, existând o corelație puternică între retorica 
religioasă și violență (Berman 2011, Hassner 2011, Isaacs 2016). În contextul atentatelor teroriste mediatizate intens, relația dintre religie și violență devine din ce în ce mai complicată (vezi Esmail 2007: 243).

\subsection{Jihadul - războiul sfânt? Coordonate de interpretare}

Literatura de specialitate semnalează traiectoria semantică și pragmatică sinuoasă a cuvântului jihad, termen complex, încărcat cu nuanțe multiple, în funcție de contextul cultural și ideologic în care a fost „transplantat”. Cu un „destin” semantic similar conceptelor decontextualizate, acesta este permanent (re)interpretat în funcție de „circumstanțele istorice și de nevoile musulmanilor” (Heck 2004: 95)33.

Tradus simplist și reductiv cu sintagma război sfânt, jihadul polarizează conotații nuanțate, de efort pentru purificarea sinelui. La o analiză mai profundă, într-un articol publicat online Barber (1992) merge mai departe de interpretările de suprafață și sesizează că jihadul nu este doar „,an instrument of policy but as an emblem of identity, an expression of community, an end in itself".

Termenul jihad înregistrează o utilizare spectaculoasă după atentatul din 11 septembrie 2001, fiind insistent exploatat de politicieni pentru a evoca imagini terifiante ale străinilor iraționali, motivați de dorința de subminare a libertăților americane. Din punct de vedere religios, jihadul este perceput însă ca o „emblemă” a islamismului. În uzul cotidian (de către cei mai mulți nonmusulmani) termenul a ajuns să fie echivalent cu ideea de „război total neîntemeiat” (Cook 2015: 1).

Interesant este că, inițial, termenul jihad, cu grafii alternative ca gihad sau djihad, avea sensul de „efort”, „luptă cu sinele” (djihad' ala nafs), gândire jalonată de anunțul Profetului care stipula că adevăratul combatant este acela care se luptă cu propriile slăbiciuni în vederea unei perfecționări pe calea divină. Treptat, cuvântul a ajuns să desemneze „Războiul sfânt” prin atributele harb („bătălie”), fitna („instigare, incitare la violență”), quital („faptul de a ucide”). Dicționarul de simboluri musulmane (Chebel 2005: 219) explică faptul că, deși războiul este, în esența sa, nefast, Războiul Sfânt sau lupta pentru Islam reprezintă o „lege divină” pentru practicanții fundamentalismului islamic.

Simbolurile încapsulează, de obicei, în formularea sugestivă a lui Paul Ricoeur (1967), „un surplus de semnificaţie”. Interpretat prin această optică, discursul profetic al Coranului (similar celui biblic), rămâne un text esențial deschis, sau, altfel spus, în termenii lui Umberto Eco o adevărată opera aperta. Așadar, textura metaforică a Coranului permite interpretări multiple, de pe poziții divergente, în funcție de contextul spațio-temporal și sociocultural, dar și de nevoile interpretului. Astfel, pentru unii cercetători musulmani, jihadul înseamnă mai degrabă un efort spiritual decât un război. În schimb, grupările radicale utilizează conceptul islamic de jihad cu „sensul de război pentru eradicarea necredincioșilor” „pentru a-și masca acțiunile teroriste”

3 „Ever-changing use of the concept of jihad according to historical circumstances and the needs of Muslims" (Heck 2004: 95). 
(Dogan 2015: 75) și a-și recruta adepți din rândul comunităţii musulmane. Violența contemporană în numele islamului (jihadismul) reprezintă, așadar, un caz care ilustrează punctele teoretice dezvoltate până acum.

În concluzie, noțiunea contemporană de jihad este reinventată, personalizată și transformată într-un instrument politic și ideologic în funcție de nevoile, interesele şi concepțiile care modelează perspectivele de interpretare.

\subsection{Terorismul jihadist: re-sacralizarea violenței ca pseudoantidot al crizei culturale a modernității}

Există puncte de vedere divergente referitoare la esența naturii terorismului. În timp ce unii contestă aspectele spirituale și teologice ale acestui fenomen (Berman 2011: 212), alții asociază terorismul cu jihadul global, pe care îl percep ca fiind expresia „unei acțiuni ce aduce la viață o revoltă islamică, nu doar împotriva hegemoniei occidentale, ci și a valorilor seculare (Hodge 2016: 20). De altfel, această tensiune este cristalizată foarte sugestiv în lucrarea lui Barber (1996), Jihad vs Mcworld.

Hodge Joel $(2015,2016)$, pornind de la „diagnoza incisivă a violenței moderne” a antropologului francez René Girard, oferă un cadru teoretic necesar pentru înțelegerea naturii și a traiectoriei violenței contemporane în contextul modernității marcate de dinamism și efervescența radicalismelor. Printr-o abordare critică, Hodge ajunge la concluzia că modernitatea parcurge o criză culturală reflectată în disoluția instituției sacrificialului care avea rolul de a controla violența, care acum frizează dimensiuni apocaliptice sub influența absenței constrângerilor religioase și culturale. Reținem ca originală teza sa, vizând resacralizarea violenței în numele totalitarismului de tip jihadist, gândită „ca un antidot la criza culturală profundă a modernității” (Hodge 2016: 231):

terrorist jihadist groups are motivated to resacralise violence as a false antidote to modernity's deepening cultural crisis. I will conclude that modern efforts at re-sacralisation (such as those of ISIS) result in the movement to totalitarianism that aims to implement an absolute system of rules, rituals and beliefs centred on appropriating the role of the archaic sacred to inflict and resolve violence (Hodge 2016: 231).

Hodge (2016: 205) susține că grupurile jihadiste se remarcă printr-o celebrare a violenței per se, în mod deschis, ceea ce antrenează în discuție ideea regizării și spectacularizării violenței (de cele mai multe ori cu complicitatea, conștientă sau $\mathrm{nu}$, a sistemului mediatic), violența în sine devenind obiectul fascinației transcendentale. Aceleași idei au fost rafinate anterior într-un articol publicat în revista online $A B C$ Religion and Ethics (Hodge 2015), unde semnalează că violența are potențialul de a imprima putere sacrală, transcendentală credințelor și ideologiei jihadiste, această sacralizare a violenței devenind ostentativ promovată în contextul actual al societății modelate de logica spectacolului.

In a similar way to a totalitarian state, jihadists sacralise violence by attributing it to God, and, by way of God, to themselves. In this way, the terrorists become the guardians of 
the divine will and order, meaning that they can target anyone for punishment or praise in the name of the Almighty (Hodge 2015).

Nevoia de glorificare a violenței motivează dorința de vizibilitate mediatică. Un punct de referință în înțelegerea relației dintre sacru și violență, îl constituie și poziția teoreticianului francez Roger Caillois referitoare la raportul dintre război, ca „matcă” a violenței și sărbătoarea primitivă „ca timp al sacrului, perioada de epifanie a divinului” (Caillois 2006: 205). Pornind de la această asociere aparent paradoxală, o examinare atentă relevă numeroase „analogii de formă și de volum” (Caillois 2006: 202), în ciuda conținutului distinct al războiului și sărbătorii.

Girard percepe potențialul apocaliptic al violenței moderne și susține că degenerarea violenței la cotele extremismului este echivalentă cu ceea ce paradigma creștină descrie ca apocalipsă. În concepția antropologului francez, violența apocaliptică nu este declanșată de intervenția punitivă a divinității, ci mai degrabă, poate fi identificată în violența umană neîncătușată (de constrângeri culturale, religioase sau instituționale). Un exemplu clar este jihadul islamist orientat asupra necredincioșilor (occidentali și islamiști nonsuuniți) pentru a instaura o „ordine sacrală nouă” (Hodge 2016: 250). Pentru a fi posibil acest lucru este nevoie de „abolirea unei ordini, a unui Cosmos, a unei structuri organice și recăderea într-o stare fluidă, amorfă, adică haotică” (Eliade 2005: 41).

\section{Clișee ale terorismului în discursul mediatic online. Aspecte ale onomasticii maladivului}

\subsection{Clișeul, de la „fosilă lingvistică” la „cod de lectură” a societății}

Prin multitudinea de funcții pe care le poate (re)activa în discurs, clișeul lingvistic, subsumat fenomenului stereotipiei, continuă să suscite interesul științific și să intrige prin profilul caleidoscopic de „paradox comunicațional” (Quéré 1998: 101). Cu toate acestea, este perceput, în general, ca o „fosilă lingvistică” (Nina 1998: IV) a limbii de lemn, afectată de „stigmatul banalității” (Amossy și Rosen 1982: 128), o „constantă a exprimării multor indivizi și instituții” (Felecan O.: 2009: 280).

În ciuda entropiei referențiale, imputată automatismelor lingvistice, utilizarea acestor structuri prefabricate în discursul mediatic reflectă, pe lângă „tendința spre brevilocvență, ca modalitate de manifestare a comodității și a minimului efort” (Felecan D. 2009: 267), și mutațiile sociopolitice dominante. Astfel, în momentele de tensiune - fie de natură economică, ideologic-religioasă sau politică la nivel (inter) național - clișeele crizei, ale catastrofalului sau ale terorismului domină discursul mediatic. Percepute drept cuvinte-martor (fr. mots- témoin) în accepția lui Guilbert (1975: 87-88), acestea ar putea juca rolul unor cuvinte-oglindă a realității evenimențiale ce reflectă o forma mentis tipică societății marcate de efervescența globalizării și de „consumul” patologic de informație: „A urmări acțiunea clișeelor în discursul public înseamnă a citi o societate prin limbajul pe care îl practică, limbaj redus la elementele sale cele mai stabile și mai lesne perceptibile” (Duda 2016: 8). 


\subsection{Aspecte pragmastilistice referitoare la numele de maladii asociate cu terorismul}

Există numeroase studii (Hülsse și Spencer 2008, Semino et al 2004, Hanne și Hawken 2007) care subliniază rolul dominant jucat de metafore în conceptualizarea terorismului ${ }^{4}$. Dintre acestea, avem în vedere contribuțiile științifice (Spencer 2012, 2010) care au ca obiect al cercetării metaforele maladivului în discursul asupra terorismului. Aceste studii demonstrează că schema de metaforizare - terorismul este o maladie violentă - domină discursul mediatic internațional, ceea ce implică excluderea, din start, a posibilității de apel la negociere și diplomație în abordarea acestui fenomen și impunerea unor măsuri radicale, de exterminare a „bolii” incurabile, vizibile în politicile antiteroriste dure.

Metaforele maladivului sunt exploatate, de altfel, și în discursul mediatic autohton pentru a taxa puncte nevralgice ale societății actuale precum lupta politică, fotbalul, corupția (a se vedea în acest sens destinul metaforei clișeizate cancerul corupției). Prin utilizarea metaforelor bolii în discursul mediatic, semnificația terorismului este potențată și încărcată cu valențe emoționale.

Corpusul nostru relevă faptul că, dintre metaforele care se înscriu în această schemă de metaforizare, s-au clișeizat, în discursul mediatic al terorismului, cu predilecție termeni care desemnează maladii grave: cancer, metastază, tumoare, cangrenă, flagel, virus, epidemie:

\section{Tumoare, metastază}

Statele Unite și aliații lor din cadrul coaliției împotriva grupării Statul Islamic s-au angajat, miercuri, să zdrobească „tumora” jihadistă în Siria și în Irak și să combată „metastazele” atacurilor islamiste din lume (http://www.stiripesurse.ro, 22 iulie 2016).

Sememul lexemului tumoră ${ }^{5}$ (vezi tumoare) este definit prin următoarele componente de sens: „/masă de țesut/ / nou/ / care se dezvoltă în organism/ / prin înmulțirea celulară / / exagerată/”. Menționăm că în $\mathrm{DEX}^{6}$ apare înregistrat cu sens strict denotativ, în timp ce analiza contextuală relevă valența metaforică de proliferare a terorismului de sorginte jihadistă. În plus, în exemplul citat anterior, sesizăm utilizarea unei metafore filate ale cărei componente aparțin aceluiași câmp lexico-semantic al maladivului. Dacă aplicăm o analiză semică termenului metastază, reținem, din complexitatea definiției lexicografice medicale („procesul de schimbare de sediu al unei boli”), trăsăturile

4 În acest sens, studii relativ recente (vezi Spencer 2012) analizează printr-o grilă constructivistă discursul mediatic din perspectiva terorismului și identifică în tabloidul britanic The Sun patru metafore conceptuale care configurează/ articulează acest fenomen pe fundația semantică a războiului, crimei, răului barbar, respectiv a bolii.

5 Menționăm că, datorită unei modificări de normă față de $\mathrm{DOOM}_{1}$, ambele forme (tumoră/tumoare) sunt acceptate în DOOM-ul actual.

6 Tumoare s. f. Masă de țesut nou format care se dezvoltă într-un organism prin înmulțirea exagerată, patologică a unor celule (DEX 1998: s.v.). 
semantice distinctive „/deplasare/ / localizare secundară/ /a unei boli/ /benigne sau maligne/". Contextul activează un sens metaforic sensibil apropiat de cel denotativ, cu trimitere la proliferarea unui fenomen negativ în sintagma metastaza atacurilor teroriste. Exploatarea acestui lanț metaforic, constituit cu ajutorul terminologiei medicale de specialitate (tumoare, metastaze) constituie, de fapt, o strategie discursivă de intensificare a potențialului expresiv și, implicit, a forței persuasive a discursului jurnalistic. Dimensiunea patologicului, configurată astfel, conjugată cu o succesiune de verbe dinamice la conjunctiv (să zdrobească, să combată) creează o imagine vizuală puternic marcată emoțional, degenerând într-un imaginar al violenței.

Metastazele Statului Islamic (www.realitatea.net, 11 septembrie 2016);

Chiar după 15 ani de la atentatele din 11 septembrie 2001, războaiele în Orientul Mijlociu, metastazele organizației jihadiste ISIS (http://romanialibera.ro, 11 septembrie 2016);

Metastazele Statului Islamic. Cu cine luptăm? Cum luptăm? (http://www.ziare.com, 24 martie 2016);

Un expert francez se teme de riscul unei metastaze jihadiste in Europa (http://www.stiripesurse.ro, 13 decembrie 2016);

Cred că aceste atacuri sunt de fapt o reprezentare a metastazelor care au cuprins Europa, generate de fundamentalismul islamic (http://www.romania-actualitati.ro, 22 martie 2016).

\section{Cancer}

$\mathrm{Cu}$ un grad mai mare de clișeizare, s-a impus sintagma cancerul terorismului, indexată metaforic, care își actualizează aici un sens distinct de cel științific, consemnat în DEX sau în dicționarele medicale. Efectul stilistic scontat al acestei metafore de tip popular (Stoichițoiu Ichim 2005: 71) este augmentat pentru că discursul publicistic mizează pe contrastul realizat între clișeul metaforic (catacreză) și contextul în care a fost inserat. Terorismului i se imprimă caracterul de boală malignă mortală și o dimensiune contagioasă - prin intermediul structurii clișeizate în combinație cu un verb care dublează, la nivel semantic, aceeași idee de expansiune.

Cancerul terorismului s-a răspândit şi printre cei care ar fi trebuit să lupte impotriva lui. Un polițist din Departamentul pentru Transporturi din Washington a fost pus sub acuzare pentru susținerea activităților organizației teroriste Stat Islamic, transmite The Washington Post. (http://www.evz.ro, 4 august 2016);

Belgique: cancer islamiste et métastases (http://www.europe-israel.org, 11 martie 2015);

Le Cancer Islamique Pourrit L' Europe! (http://realitesdefrance.unblog.fr, 24 martie 2016).

\section{Flagel}

În aceeași izotopie a maladivului se înscrie și lexemul flagel, care condensează din definiţia termenului medical semul /expansiune/, lexemul fiind utilizat pentru a 
desemna gravitatea și răspândirea mare a unor boli. Acesta intră în tipare de construcție, în special cu modalizatori și verbe puternice, uneori recrutate chiar din familia lexicală a clișeului analizat, teroare, miza persuasivă fiind dublată și la nivel fonetic: Flagelul terorismului terorizează SUA (http://www.cotidianul.ro, 3 mai 2010).

O altă greşeală făcută în ceea ce priveşte percepțtia fenomenului terorist este asocierea acestui flagel doar cu lumea musulmană şi, implicit, cu ideologia jihadistă, lucru total neadevărat, căci acesta a însoțit societatea umană încă din cele mai vechi timpuri (http://adevarul.ro, 23 august 2014);

Atentatele din 11 septembrie 2001. Europarlamentarul Viorica Dăncilă: Rănile nu s-au cicatrizat nici după 15 ani pentru că flagelul terorismului pare mai prezent ca oricând (http:// www.caleaeuropeana.ro, 11 septembrie 2016).

Prezența formulei clișeizate alături de modalizatorul $\mathrm{cu}$ valoare epistemicevidențială pare contribuie la ancorarea problemei terorismului într-un spațiu al actualităţii marcate de insecuritate.

Cioloş şi Iohannis, reacții aspre după atacul din Nisa: „Flagelul terorismului trebuie combătut" (http://www.ziarulevenimentul.ro, 15 septembrie 2016).

Interesant de observat este că formula clișeizată (flagelul terorismului) în combinație cu modalizatorul deontic prescriptiv permite construcția [trebuie + participiu] cu elipsa operatorului de agent, ceea ce, în subsidiar, antrenează o plasare a responsabilităţii unei asemenea sarcini controversate în domeniul vagului (nu se știe cine), fiind expresia unei (pseudo)asumări.

\section{Sindrom}

Într-un studiu axat pe onomastica recognoscibilă în nomenclatorul medical, cu referire la numele de maladii, simptome, virusuri, Siserman şi Munteanu Siserman (2015: 826) identifică, în structura denominativă a unor boli, expresii designative din terminologia medicală care „actualizează prin ocurența unui toponim zona de manifestare, de incidență a maladiei/virusului respectiv: sindromul Stockholm, virusul Ebola (hidronim)". Pe același procedeu, în contextul discursului mediatic despre terorism, înregistrăm ocurența termenului sindrom, particularizat spațial printr-un toponim, care, de această dată, are funcție anamnetică/anaforică, subtitlul informațional narativ făcând trimitere la atentatul precedent care a avut loc în capitala spaniolă, respectiv a Angliei.

Subtitlu: Englezii trăiesc acasă sindromul Madrid (http://jurnalul.ro, 8 iulie 2005); Cele mai negre coșmaruri ale autorităţilor britanice par a se fi împlinit. Unii experți vorbesc deja despre un atentat coordonat și simultan, în „stilul” binecunoscut de-acum al rețelei teroriste Al-Qaeda, de genul celui care a avut loc la 11 martie, anul trecut, în gările din Madrid (http://jurnalul.ro, 8 iulie 2005);

Sindromul Londra „07/07” (http://adevarul.ro, 21 august 2007). 


\section{Virus, epidemie, febră}

Aceste clișee sunt preferate în titluri incitative în asociere cu un verb puternic. Lexemele febră, epidemie, virus, flagel aparțin, de asemenea, paradigmei termenilor încadrați în sfera lexico-semantică a maladivului. Uneori apar în contexte cu verbe marcate semantic prin /grad de răspândire/, /hipertrofie/, ca de exemplu a se infiltra, a se infecta, a cangrena, termen utilizat pentru a desemna gravitatea și gradul de răspândire a terorismului.

Terorismul, cea mai oribilă „boală” a acestui secol, se infiltrează din ce în ce mai mult într-o Europă vulnerabilă, permisivă, chiar lipsită de reacție uneori. (...) Atunci când ne aflăm în mod evident in fața unei Europe vulnerabile și infectată de virusul terorismului, incapabilă să integreze diferitele valuri de migrație pe care le-a atras, nu mai putem spera să exportăm securitate și prosperitate în țările din vecinătate (http://www.caleaeuropeana.ro, 22 martie 2016);

Atentatele teroriste nu mai sunt o excepție, ci tind să devină o regulă. Paris, Bruxelles, Nisa și lista va continua, cu siguranță. Explicațiile sunt multiple. Una dintre ele este că aceste atentate sunt epidemice (http://www.romanialibera.ro, 20 iulie 2016);

Cum a fost cuprinsă România de febra atentatelor teroriste. O căruță-capcană a inspăimântat un sat din Bihor (http://adevarul.ro, 17 ianuarie 2015);

Grav afectate se văd, implicit, şi alianța nord-atlantică, precum şi SUA, care au interese strategice majore într-o regiune cuprinsă de febra islamismului militant, de conflictele din Irak şi Afganistan şi, mai cu seamă, de pericolul înarmării nucleare iraniene (http://www.dw.com, 7 iunie 2010).

Așadar, din acest unghi de abordare, terorismul poate fi perceput prin dimensiunea patologicului, a hipertrofiei. Dacă luăm în considerare punctul de vedere biblic al Vechiului Testament asupra bolii (vezi Dicționar biblic 1995: 1168), devine clară legătura ombilicală dintre boală și „originea răului însuși”.

\section{Concluzii}

Demersul investigativ a fost orientat, așadar, într-o primă etapă, înspre clarificarea sintagmei oximoronice de „război sfânt”, cu care este frecvent etichetat jihadismul și nu numai (vezi cruciadele). Dincolo de această asociere între violență și sacralitate, aparent paradoxală pentru omul modern, ne-a interesat în ce măsură putem admite ca ipoteză de lucru validă ideea unei învestiri cu sacralitate a violenței, în speță a jihadismului. Pentru aceasta ne-am raportat, desigur, la contribuțiile semnificative ale antropologului francez René Girard. Am sesizat, astfel, un circuit interesant între efortul de resacralizare a violenței jihadiste - ca modalitate de legitimare și de câștigare de adepți în lumea islamică - și tentativa occidentală axată pe desacralizarea jihadismului. Sacrul poate deveni, așadar, un artificiu retoric, manipulabil în funcție de interesele actorilor Această tendință se materializează într-un discurs mediatic care „alimentează” anxietatea, exploatând izotopia maladivului letal, în special prin intermediul clișeelor mediatice, care se comportă ca un filtru cu ajutorul căruia este selectată și tratată informația 
(vezi Duda 2016: 73). Faptul că schema de metaforizare terorismul este o maladie domină discursul mediatic autohton denotă faptul că se aliniază celui internațional, ceea ce implică excluderea, din start, a posibilității de apel la negociere și diplomație în „tratatarea”/abordarea acestui fenomen și impunerea unor măsuri radicale, de exterminare a „bolii” incurabile, vizibile în politicile antiteroriste dure.

\section{Bibliografie}

Amossy, R., E. Rosen. 1982. Les Discours du cliché. Paris: Sedes.

Barber, B. 1992. Jihad vs. McWorld. The Atlantic Monthly (March 1992). https://www.theatlantic.com/past/docs/politics/foreign/barjiha.htm (accesat în 3 iulie 2017).

Barber, B. 1996. Jihad vs. McWorld. How Globalism and Tribalism are Reshaping the World. New York: Ballantine Books.

Baudrillard, J. 1988. Simulacra and Simulations. În Selected Writings, Mark Poster (ed.), 166184. Stanford: Stanford University Press,.

Baudrillard, J. 2002. The Spirit of Terrorism and Requiem for the Twin Towers. Chris Turner (trad.). Londra: Verso.

Berman, E. 2011. Radical, Religious, and Violent: The New Economics of Terrorism. Cambridge, MA: MIT Press.

Caillois, R. 2006. Omul și sacrul. București: Editura Nemira.

Chebel, M. 2005. Dicționar de simboluri musulmane. Rituri, mistică şi civilizație. Catrinel Auneanu (trad.). Piteşti: Editura Paralela 45.

Coman, M. 2003. Mass media, mit și ritual. O perspectivă antropologică. Iași: Editura Polirom.

Cook, D. 2015. Understanding Jihad. Univ. of California Press.

David, I. 2015. Mass-media şi terorismul contemporan. ComUnique (10-12). http://www. comunique.ro/2015/04/dr-ion-david-mass-media-si-terorismul.html (accesat în perioada aprilie-mai 2017).

Delcea, C., A. Bădulescu. 2008. Terorismul. Studii și cercetări asupra fenomenului terorist. http:// server2.docfoc.com/uploads/Z2015/12/04/2Z7RTZ9UeN/ 198581000779647bf902244 9305442ea.pdf (accesat în perioada octombrie-noiembrie 2016).

DER - Dicționarul etimologic al limbii române. 2001. Ciorănescu, A. București: Editura Saeculum.

Diaz Gandasegui, V. 2009. Spectators after 9/11: This Is (not) like a Hollywood Film. http:// earchivo.uc3m.es/bitstream/handle/10016/11279/Spectators\%20after\%20911.pdf?sequence $=1$ (accesat în data de 25 octombrie 2016).

Dogan, R. 2015. Global Terrorism and Islamic Radicalization: Analysis from Fethullah Gülen's Perspective. International Journal of Religion \& Spirituality in Society 6 (1).

Duda, G. 2016. Clişeul verbal şi discursul public. Bucureşti: Editura Academiei.

Eliade, M. 2005. Sacrul și profanul. București: Editura Humanitas.

Esmail, A. 2007. Towards a Psycho-anthropological View of Religious Violence. International Review of Psychiatry 19 (3): 243-251.

Felecan, D. 2009. Structuri clișeizate în horoscopul mediatic. În Limba de lemn în presă, Ilie Rad (ed.), 263-279. Bucureşti: Editura Tritonic.

Felecan, O. 2009. Limba de lemn în mesajele funerare de la mica publicitate. În Limba de lemn în presă, Ilie Rad (ed.), 280-293. Bucureşti: Editura Tritonic.

Frattasio, A. 2006. Epistemologia terorii. București: Editura Era.

Garcin-Marrou, I. 2005. Media vs. Terorism. București: Editura Tritonic. 
Girard, R. 1995. Violența şi sacrul. Mona Antohi (trad.). București: Editura Nemira.

Guilbert, L. 1975. La créativité lexicale. Paris: Editura Larousse.

Hanne, M., S. J. Hawken. 2007. Metaphors for Illness in Contemporary Media. Medical Humanities 33 (2): 93-99. http://mh.bmj.com/content/33/2/93 (accesat în data de 12 iulie 2017).

Hassner, R. E. 2011. Religious intelligence. Terrorism and Political Violence 23 (5). http:/ / www. tandfonline.com/doi/full/10.1080/09546553.2011.598197 (accesat în data de 8 iulie 2017).

Heck, P. L. 2004. Jihad Revisited. Journal of Religious Ethics 32 (1): 95-128. http://faculty. georgetown.edu/plh2/Jihad.Revisited.pdf (accesat în 10 iulie 2017).

Hodge, J. 2015. Without Restraint: Girard, Jihadism and the Hypocrisy of Sacred Violence. În $A B C$ Religion and Ethics. http://www.abc.net.au/religion/articles/2015/11/16/4353068. htm (accesat în 19 iulie 2017).

Hodge, J. 2016. Terrorism's Answer to Modernity's Cultural Crisis: Re-sacralising Violence. The Name of Jihadist Totalitarianism, Modern Theology 32 (2): 231-258.

Hudson, R. A., M. Majeska. 1999. The Sociology and Psychology of Terrorism: Who Becomes a Terrorist and Why? Washington, DC: Library of Congress. https://www.loc.gov/rr/frd/pdffiles/Soc_Psych_of_Terrorism.pdf (accesat în 30 octombrie 2016).

Hülsse, R., A. Spencer. 2008 . The Metaphor of Terror: Terrorism Studies and the Constructivist Turn. Security Dialogue 39 (6): 571-592. https://www.researchgate.net/profile/Alexander Spencer2/publication/263327483_The_social_construction_of_terrorism_Media_metaphors_and_policy_implications/links/5624fa7008ae93a5c92d427e.pdf (accesat în 2 mai 2017).

Isaacs, M. 2016. Sacred Violence or Strategic Faith? Disentangling the Relationship Between Religion and Violence in Armed Conflict. Journal of Peace Research 53 (2): 211-225. http:// journals.sagepub.com/doi/pdf/10.1177/0022343315626771 (accesat în 9 iulie 2017).

Jongman, A., A. P. Schmid. 2017. Political Terrorism: A New Guide to Actors, Authors, Concepts, Data Bases, Theories, and Literature. Routledge.

Kay, M. 1979. Lexemic Change and Semantic Shift in Disease Names. Culture, Medicine and Psychiatry 3 (1): 73-94.

Kellner, D. 2015. Media Spectacle and the Crisis of Democracy: Terrorism, War, and Election Battles. https://pages.gseis.ucla.edu/faculty/kellner/essays/mediaspectacletocintro.pdf (accesat în perioada mai-iulie 2017).

Nina, A. J. 1998. La traduction du cliché dans les textes pragmatiques: définition, repérage, équivalences. http://www.ruor.uottawa.ca/bitstream/10393/4300/1/MQ36729.PDF (accesat în perioada august-septembrie 2016).

O’Brien, P. 2016. The Muslim Question in Europe. http://www.jstor.org/stable/j.ctt1kft8dx.9 (accesat în 19 mai 2017).

Quéré, H. 1998. Le cliché: pour ou contre. În Le cliché, Mathias Gilles (ed.), 101-112. Toulouse: Presses Universitaires du Mirail.

Ricoeur, P. 1967. The Symbolism of Evil. New York: Beacon Press.

Scott, A. 2000. The Ambivalence of the Sacred: Religion, Violence and Reconciliation. Lanham, MD: Rowan and Littlefield.

Semino, E., J. Heywood, M. Short. 2004. Methodological Problems in the Analysis of Metaphors in a Corpus of Conversations about Cancer. Journal of Pragmatics 36 (7): 1271-1294.

Siserman, C., M. Munteanu Siserman. 2015. Considerații privind denominația medicală. 
In Proceedings of the Third International Conference on Onomastics "Name and Naming". Conventional/Unconventional in Onomastics, O. Felecan, 819-829. Cluj-Napoca: Mega, Argonaut.

Spencer, A. 2010. The Tabloid Terrorist: The Predicative Construction of New Terrorism in the Media. New York: Palgrave Macmillan.

Spencer, A. 2012. The Social Construction of Terrorism: Media, Metaphor and Policy Implications. Journal of International Relations and Development 15 (3): 393-419. http:// www.palgrave-journals.com/jird/journal/v15/n3/pdf/jird20124a.pdf (accesat în data de 25 octombrie 2016).

Stoichițoiu Ichim, A. 2005. Vocabularul limbii române actuale. Dinamică, influențe, creativitate. Bucureşti: Editura All.

Wieviorka, M. 2004. The Making of Terrorism. Chicago: University of Chicago Press.

Wilkinson, P. 1997. The Media and Terrorism: A Reassessment. Terrorism and Political Violence 9 (2): 51-64. http://magellanpr.hu/files/terrorism.pdf (accesat în perioada septembrie-octombrie 2016). 